\title{
Morfologi Bahasa Melayu Manado
}

\author{
Vany Kamu \\ Ilke J. Moniung \\ Fakultas Ilmu Budaya \\ Universitas Sam Ratulangi
}

\begin{abstract}
Indonesia as a country possess many local wisdoms as well as many variatyes of local languages. It has been the unvaluable richness which needs attention and prevention. The prevention is very valuable in the field of language maintenance in order to prevent the language vasihment in the form of written and oral. This article emphasized on the understanding of society toward the development of Manadonese Malay in the revitalization process. Morphological process of Manadonese Malay can be done by classifying the local language by using Nida's theory.
\end{abstract}

Keywords: Morphology, Manadonese, Malay

\section{Latar Belakang}

Salah satu aset leluhur yang dimiliki oleh bangsa Indonesia hingga kini dengan banyak ragamnya yakni bahasa daerah. Beragamnya bahasa daerah yang dipakai di tiap daerah merupakan kekayaan yang sangat bernilai dan perlu mendapat perhatian serta penggarapan yang sepatutnya. Penanganan tersebut sangat bernilai bagi bidang kebahasaan mengingat ada banyak bahasa yang telah lenyap tanpa menyisakan data baik lisan maupun tulisan.

Menyingkapi peran bahasa daerah, sangatlah tepat jika dikaitkan dengan kedudukan dan fungsi bahasa daerah sebagaimana yang ditetapkan oleh Politik Bahasa Nasional (Halim, 1981:30) yang antara lain menyatakan bahasa daerah berkedudukan sebagai bahasa daerah. Dalam kedudukannya ini bahasa daerah berfungsi sebagai (1) lambang kebanggaan daerah, (2) lambang identitas daerah, (3) alat perhubungan di dalam keluarga dan masyarakat, dan (4) alat pengembangan serta pengungkap kebudayaan daerah. Berkaitan dengan hal tersebut di atas, Silzer (dalam Nababan 1990:3) juga menyatakan bahwa setiap bahasa dipakai dalam beberapa fungsi kebudayaan, bahasa berperan sebagai (1) sarana pengembangan dan pengungkap kebudayaan, (2) sebagai penerus kebudayaan, dan (3) sebagai inventaris ciri-ciri kebudayaan. Berdasarkan keterangan tersebut maka bahasa daerah berhak mendapat tempat sendiri yang lebih terhormat dan lebih layak.

Imbang (2008) mengungkapkan bahwa Bahasa Melayu Manado dipakai oleh penduduk Sulawesi Utara dalam kehidupan sehari-hari ketika berkomunikasi antar suku yang telah menetap di Manado dan sekitarnya. Penggunaan bahasa Melayu oleh penuturnya berdampingan dengan bahasa Indonesia, bahasa daerah, dan bahasa asing. Hal tersebut menunjukkan bahwa Bahasa Melayu Manado merupakan alat komunikasi utama dalam masyarakat.

Bahasa Melayu Manado (BMM) sebagai alat komunikasi digunakan dalam hampir semua aktivitas kehidupan bersosial yang terdapat di Sulawesi Utara. Bahasa ini digunakan sebagai bahasa perhubungan antaretnis di Sulawesi Utara juga sebagai bahasa ibu bagi masyarakat Sulawesi Utara, sehingga kedudukan bahasa Melayu Manado dikategorikan sebagai bahasa regional atau bahasa pemersatu di Sulawesi Utara. Bahasa Melayu Manado memiliki kesamaan 
dengan bahasa Melayu di beberapa tempat di kawasan timur Indonesia seperti Melayu Papua, Melayu Ambon, Melayu Ternate, dan Melayu Nusa Tenggara. Sehubungan dengan hal tersebut Alwi, (2003:2) menjelaskan bahwa jenis kreol bahasa Melayu Indonesia, yakni Melayu Indonesia yang bercampur dengan bahasa setempat, didapati masih jamak ditemui dalam proses komunikasi di kalangan masyarakat di Sulawesi Utara.

Bahasa Melayu manado merupakan bahasa lingua franca yang mempersatukan banyak masyarakat dari latar belakang yang berbeda baik latar belakang pendidikan, asal daerah maupun kehidupan sosial. Maraknya pemakaina bahasa melayu manado dalam pemakaina sehari-hari membuat para pendatangpun harus menyesuaikan diri dalam berbahasa agar tidak diangap sebagai orang luar, namun setelah banyak kata serapan yang hadir di masyarakat membuat bahasa melayu manado semakin meriah dalam pemakaiannya. Pertumbuhan platform digital dalam masyarakat baik dalam tontonan yang didasarkan pada televise maupun televise berbayar membuat ada banyak kata, frase, klausa bahkan kalimat yang akhirnya dipakai dalam percakapan sehari-hari bersama bahasa melayu manado.

Proses masuknya kata, frase, klausa maupun kalimat dalam formasi kalimat Bahasa Melayu Manado dapat mengakibatkan Bahasa Melayu Manado memiliki bentuk yang nantinya akan merubah baik struktur frase, kalusa maupun kalimatnya. Apabila terdapat banyak bahasa serapan yang didapat baik dari tontonan maupun percakapan maka pada akhirnya Bahasa Melayu Manado akan memiliki struktur yang baru atau diperluas sesuai dengan perkembangan jaman dan modernisasi.

Penelitian ini bertujuan untuk mendeskripsikan, menganalisis, dan menguraikan proses revitalisasi struktur Bahasa Melayu Manado dalam proses pengembangan bahasa dan budaya lokal dapat terancam oleh masuknya dan banyaknya bahasa serapan yang digunakan dalam masyarakat yang terdapat di tujuh kota dan kabupaten di Sulawesi Utara.

\section{Tinjauan Pustaka}

Menurut Achmad \& Abdullah (2012: 3), bahasa merupakan sistem lambang bunyi yang arbitrer, yang digunakan oleh anggota suatu masyarakat untuk bekerja sama, berinteraksi, dan mengidentifikasikan diri. Chaer dan Agustina (2010: 11) berpendapat bahwa bahasa adalah sebuah sistem, artinya, bahasa itu dibentuk oleh sejumlah komponen yang berpola secara tetap dan dapat dikaidahkan. Tarigan dalam Suyanto (2016: 15) memberikan dua definisi bahasa. Pertama, bahasa adalah suatu sistem yang sistematis, juga untuk sistem yang generatif. Kedua, bahasa adalah seperangkat lambang-lambang mana suka atau simbol-simbol arbitrer. Dari beberapa pendapat di atas dapat disimpulkan bahwa bahasa adalah alat untuk menyampaikan ide, pikiran, perasaan, atau kehendak dengan menggunakan lambang bunyi yang dihasilkan oleh alat ucap manusia.

Penelitian ini menekankan pemahaman dari masyarakat terhadap proses pengembangan bahasa Melayu Manado dalam tahapan revitalisasi untuk mendapatkan perkembangan terbaru yang ada di masyarakat. Proses pemaduan yang secara kasat mata terus terjadi tanpa dapat dicegah secara terus menerus dapat membuat masyarakat mulai meniru atau menggunakan baik kata, frase, klausa bahkan kalimat yang didapat dari bahasa serapan yang muncul dalam bentuk tontonan televise konvensional, tontonan televise digital, platform media sosial, maupun maraknya tontnan drama korea.

Pantouw (2018) menggambarkan bahasa Melayu Manado sebagai bahasa yang memiliki proses sinonim nomina yang beragam yang didapat dari beberapa kata serapan dalam masyarakat itu sendiri. Demikian pula Imbang (2008) yang menjelaskan tentang bentuk makna dan fungsi 
kata tugas dalam bahasa Melayu Manado yang memiliki pola-pola tertentu yang terdapat dalam masyarakat. Preposisi Bahasa Inggris dan Bahasa Melayu Manado" oleh Lumiwu (2017) dalam penelitian ini Lumiwu menggunakan teori Aarts and Aarts (1982) dia membahas mengenai persamaan dan perbedaan antara preposisi dalam bahasa Inggris dan bahasa Melayu Manado. Dalam penelitian tersebut dia menyimpulkan kalau preposisi dalam bahasa Inggris dan bahasa Melayu Manado terbagi dalam dua bentuk, yaitu bentuk sederhana dan bentuk kompleks. Nurdin (20150 menulis tentang Fungsi adverbial bahas Melayu Manado kemudian mendapati terdapat struktur adverbial yang terdiri dari bentuk kata, frase maupun klausa.

Menyingkapi masalah bahasa tersebut, Chaer (1994:51) mengatakan bahwa Bahasa itu unik, unik berarti mempunyai ciri khas yang spesifik dan tidak dimiliki oleh bahasa lain. Oleh karena itu tidak ada bahasa yang lebih tinggi dari bahasa lain. Keunikan bahasa tersebut juga dapat ditemukan dalam kalimat-kalimat yang digunakan dalam iklan papan yang banyak bertebarandi sekitar kita. Struktur kalimat yang unik tersebut mampu membius para konsumen karena rasa keingintahuan serta ketertarikannya maka timbullah rasa ingin memiliki produk yang ditawarkan. Kekhasan struktur kalimat iklan antara lain singkat, padat, jelas, dan menarik. Maka dari itu diperlukan pemilihan kata yang tepat dan gaya bahasa.

Pengembangan bahasa Melayu Manado sebagai bahasa daerah harus dilakukan dengan maksimal mengingat banyaknya serangan yang tidak disadari oleh banyak pihak. Seranganserangan tersebut berupa maraknya penggunaan kata, frase, klausa dan kalimat yang berupa serapan dari bahasa asing yang didapat baik dari media cetak, media sosial, tayangan televise, dan streaming film pada patform digital. Dengan adanya proses pemertahanan bahasa dan budaya yang dapat ditampilkan diharapkan dapat meminimalisisr proses penghilangan kemampuan masyarakat dalam memilah-milah konsep penggunaan kata serapan dalam masyarakat.

1. Tuju. E. 1988. Kalimat minor dalam Bahasa Inggris dan dalam Bahasa Melayu Manado. Suatu analisis konstrastif.

Kalimat minor vokatif dan Fragmen kompletif khusus adalah dua jenis kalimat minor bahasa MelayuManado.

2. Lengkong. J. 2001. Interferensi Bahasa Inggris dalam Bahasa Melayu Manado.

Adanya interferensi dalam tataran fonologi, garammar, lexicon dan kalimat pada Bahasa Melayu Manado oleh Bahasa Inggris.

3. Mandang. S. 1987. Analisis Konstrastif kata majemuk Bahasa Inggris dan Bahasa Melayu Manado.

Adanya empat kategori kata majemuk dalam bahasa Melayu Manado.

1. Kata majemuk benda.

2. Kata majemuk aktiva

3. Kata majemuk kerja

4. Partikel

4. Lalamentik, dan Warouw. 1986. Partikel bahasa Melayu Manado.

Partikel berbentuk dasar dan yang membentuk turunan ada dua macam dalam bahasa Melayu Manado.

Menurut Nida, morfologi mempunyai definisi yakni "kajian tentang morfem dan penataannya dalam pembentukan kata." Sehubungan dengan itu dalam morfologi terjadi dua pokok bahasan yaitu tentang morfem dan pembentukannya.

Menurut Gleason (1961:2) morfem adalah unit terkecil dari struktur bahasa yang memiliki makna, sedangkan menurut Nida morfem adalah unit-unit terkecil yang memiliki 
makna yang terdiri dari kata atau bagian kata. Bloomfield juga memberikan definisi sebagai berikut, morfem merupakan bentuk bahasa yang sebagiannya tidak mirip dengan bentuk lain manapun juga baik bunyi maupun arti.

Dalam hal ini morfem tersebut dapat dibagi kedalam dua komponen yaitu morfem bebas yaitu morfem yang memiliki arti atau makna tanpa membutuhkan pelekatan pada unsur-unsur lainnya, sedangkan morfem terikat adalah morfem yang tidak memiliki makna apabila tidak dilekatkan pada bentuk dasar atau morfem dasar dari suatu bahasa.

- Contoh morfem bebas : tidur, meja, kemarin,dll.

Kesemuanya mempunyai arti yang dapat diklasifikasikan kedalam kelas-kelas kata seperti kelas kata benda, kelas kata kerja, dsb.

- Contoh morfem terikat : se-, me-, ter-, di-,dsb.

- Contoh dalam penggunaan, morfem bebas "tidur" yang diberi prefiks ter- akan menjadi gabungan morfem "tertidur" yang berarti sudah tidur. Morfrem terikat dapat berdistribusi pada awal, tengah, akhir ataupun penggabungan kesemua morfem terikat yang disebut afiksasi.

Dalam mengidentifikasi morfem Nida memberikan enam prinsip yang secara singkat dapat ditunjukan hasil penerapannya

Langkah yang ditempuh setelah mendapatkan morfem-morfem yaitu pada proses pembentukan kata. Hal tersebut dapat dilakukan lewat dua cara yaitu dengan proses morfologis dan non proses morfologis.

1. Proses morfologis, yaitu proses pembentukan kata dengan :

a. Afiksasi, yaitu dengan penambahan afiks pada awal (prefiks),pada tengah (infiks), pada akhir (sufiks) dan pada semua posisi (konfiks).

b. Pemajemukan yang meliputi empat cara, yaitu:

1. Sintaktik, yaitu pemajemukan yang mengikuti pola bahasa

2. Asintaktik, yaitu pemajemukan yang tidak mengikuti pola bahasa.

3. Endosentris, yaitu perubahan kedalam yang hasilnya sama dengan inti.

4. Eksosentris, yaitu perubahan keluar yang hasilnya berbeda dengan inti.

c. Pengulangan yaitu pembentukan kata baru dengan melakukan pengulangan bentuk kata yang terdiri atas:

- pengulangan kata dasar.

- pengulangan sebagian.

- pengulangan berubah bunyi.

d. Perubahan kedalam, misalnya goose /guwz/ menjadi gesse /giyz/.

e. Pembentukan kosong (zero modifiation), yaitu tidak adanya perubahan pada kata tersebut walapun mengalami perubahan jumlah seperti pada kata deer yang dapat menunjukan baik tunggal maupun jamak.

\section{f. Proses suplisi.}

\section{Metode Penelitian}

Penelitian ini menggunakan rancangan penelitian deskriptif untuk menjawab masalah penelitian. Penelitian deskriptif dengan metode kuantitatif dianggap cocok berdasarkan apa yang ingin dicapai dalam penelitian ini. Bogdan dan Taylor (Moleong, 2007:3) mengemukakan bahwa metodologi kualitatif adalah prosedur penelitian yang menghasilkan data deskriptif berupa katakata tertulis maupun lisan dari orang-orang dan perilaku yang diamati. Djajasudarma (1993: 8), menyatakan bahwa penelitian deskriptif bertujuan untuk membuat deskriptif, yaitu membuat 
gambaran, lukisan secara sistematis, faktual dan akurat mengenai data, sifat-sifat serta hubungan fenomena yang diteliti.

Djajasudarma (1993: 10) menjelaskan, penelitian kualitatif merupakan penelitian yang menghasilkan data deskriptif berupa data tertulis atau lisan dari masyarakat. Berdasarkan pernyataan tersebut dapat disimpulkan, penelitian kualitatif menghasilkan deskriptif data, kemudian deskriptif data tersebut digali hingga mendapatkan hipotesis yang konsisten.

Arikunto (2010) mendefinisikan survey sebagai prosedur penelitian yang digunakan peneliti pada sampel atau seluruh populasi penelitian untuk mendeskripsikan sikap, pendapat, tingkah laku atau karakteristik populasi. Obyek penelitian ialah struktur kalimat yang terdapat pada bahasa Melayu Manado yang diapkai dalam percakapan sehari-hari di tujuh kota dan kabupaten di Sulawesi Utara.

Imbang (2008) mengatakan dalam setiap aktivitas, cenderung penggunaan bahasa Melayu Manado semakin nyata karena dipakai sebagai alat komunikasi tidak resmi dalam kehidupan masyarakat yang beragam suku, juga dalam kegiatan masyarakat yang heterogen. Berdasarkan pemakaian yang massif dari bahasa Melayu Manado maka aspek kebahasaan, seperti fonologi, morfologi, sintaksis yang mengemban makna leksikal dan makna gramatikal. Makna leksikal ditelusuri dalam empat kelas kata, yakni nomina, verba, adjektiva, dan adverbial sedangkan makna gramatikal ditelusuri dalam kata tugas.

Proses morfologis adalah suatu proses pembentukan kata dengan cara menghubungkan satu morfem dengan morfem yang lain atau proses yang mengubah leksem menjadi sebuah kata. Pengafiksan adalah proses pembentukan kata dengan menambahkan afiks (imbuhan) pada bentuk dasar, baik bentuk dasar tunggal maupun kompleks. Proses morfologis pada dasarnya adalah proses pembentukan kata dari sebuah bentuk kata dasar melalui pembubuhan afiks, pengulangan, penggabungan, pemendekan, dan pengubahan status (Chaer, 1998:25). Proses morfologis adalah suatu proses pembentukan kata dengan cara menghubungkan satu morfem dengan morfem yang lain atau proses yang mengubah leksem menjadi sebuah kata.

\section{Pembahasan}

Bahasa Melayu Manado memiliki proses morfologis yang dapat diterapkan pada bentukbentuk kata yang merupakan bagian dalam bahasa. Proses afiksasi yang terjadi dapat juga duterpakan dalam bentuk penambahan prefiks, sufiks dan konfis. Berikut merupakan penjelasan proses morfologis terhadap bahasa Melayu Manado:

1. Prefiks (ba-) apabila diikuti oleh verba akan memiliki makna penanda kala sedang melakukan atau kata kerja aktif.

Contoh : $\quad$ dia da bacirita dey depe tamay

'dia sedang bercerita dengan temannya'

ba + cirita menjadi bacirita 'bercerita'

2. Prefiks (ba-) akan membentuk kata kerja dari kata sifat.

Contoh : dia so bakuat katu

'dia sudah berusaha'

ba + kuat bakuat 'berusaha'

3. Prefiks (ba-) akan membentuk kata kerja dari kata benda.

Contoh : $\quad$ ta so batamu tadi malay

'saya sudah bertamu tadi malam'

ba + tamu menjadi batamu 'bertamu'

Prefiks (ba-) akan membentuk kata kerja mandiri (reflektif) 
Contoh : $\quad$ dia so babantin 'dia membanting diri sendiri' ba + bantin menjadi babantin 'membantingkan diri'

4. Prefiks (ba-) bila diikuti oleh nomina akan bermakna memiliki kecuali untuk kata 'hitar' akan bermakna 'sedang bermain gitar'

Contoh : dia so baruma dua 'dia sudah mempunyai dua buah rumah' ba + ruma menjadi baruma 'mempunyai rumah'

5. Prefiks (ba-) akan berkontras dengan bra- apabila diikuti oleh fonem /a/ seperti pada kata /anak/ dan /i/ pada /ijus/ yang berarti memiliki

Contoh : dia sobrana? dua 'dia sudah mempunyai dua orang anak'

Prefiks (ba-) bila diikuti oleh ajektiva akan berarti sudah mulai berubah dari satu bentuk ke bantuk lainnya.

Contoh : om perambut sobaputih 'rambut om tersebut mulai menjadi putih' ba + putih menjadi baputih 'sudah mulai memutih'

6. Prefiks (baba-) apabila diikuti oleh verba akan berarti sesuatu yang hanya dilakukan itu itu saja.

Contoh : $\quad$ depe karja babamakay jo

'kerjanya hanya makan - makan saja'

baba + makay menjadi babamakay 'hanya makan-makan saja'

7. Prefiks (baku-) berarti :

a. Melakukan perbuatan yang tersebut pada akar kata dengan berbalas-balasan.

Contoh : doran da bakupukul

'mereka sedang saling memukul'

baku + pukul menjadi bakupukul 'saling memukul'

b. Dua hal yang yang berada dalam keadaan seperti apa yang tersebut pada akar kata dan membentuk kata sifat.

Contoh : tu warna kwa bakulaen

'warnanya berlainan'

baku + laen manjadi bakulaen 'saling berlainan'

8. Prefiks (pa-) merupakan penanda persona apabila diikuti oleh verba.

Contoh: tu pancuri so dapa tayka

'pencuri itu sudah tertangkap'

/pan/ + /curi/ menjadi /pancuri/ 'pencuri'

9. Prefiks (pa-) apabila diikuti oleh ajektiva akan bermakna meiliki.

Contoh : user tu oran pañaki kasana!

'usir orang yang berpenyakit itu kesana'

/pa/ + /ñaki/ menjadi /pañaki/ 'berpenyakit'

10. Prefiks (pa-) akan menjadi paN - + kk yang berarti :

a. membentuk kata benda dari kata kerja.

Contoh : $\quad$ /paN/ + /curi/ menjadi /pancuri/ 'pencuri'

/paN/ + /badusta/ menjadi /paybadusta/ 'tukang berdusta' 


$$
\text { /paN/ + /baf\&to/ menjadi /paybafeto/ 'pemarah' }
$$

b. Benda yang berfungsi seperti apa yang terdapat pada akar kata yang membentuk kata benda dari kata kerja.

Contoh : $\quad / \mathrm{paN} /+/ \mathrm{p} \varepsilon l \varepsilon /$ menjadi /pam pele/ 'tirai'

c. Bersifat seperti apa yang tersebut pada akar kata.

$$
\text { Contoh: /paN/ + /bae/ menjadi /paybae 'peramah' }
$$

d. Membentuk kata benda agentif dari kata benda.

Contoh : / /paN/ + /doti/menjadi /pandoti/ 'peracun'

e. Membentuk kata benda agentif dari kata sifat.

Contoh : $\quad / \mathrm{paN} /+/ \mathrm{malo} /$ menjadi /pamalo/ 'pemalu'

11. Prefiks (ta-) akan memiliki :

a. Arti sesuatu yang tidak disengaja.

Contoh: kita tamakay tupait

'saya termakan sesuatu yang pahit'

/ta/ + /makay/ 'termakan'

b. Menyatakan keadaan seperti apa yang tersebut pada akar kata atau kata kerja pasif.

Contoh : tatutu no tu pintu

'pintu itu tertutup

$/ \mathrm{ta} /+/ \mathrm{tutu} / \quad$ 'tertutup'

c. Membentuk kata kerja kausatif.
Contoh :
$/ \mathrm{ta} /+/ \mathrm{ba \varepsilon} /$
menjadi
/tabae/
'menjadi baik'

d. Membentuk kata kerja dari kata keterangan.
Contoh :
/ta/ + /kaatas/ menjadi
/takaatas/
'terangkat keatas'

12. Prefiks (mo-) akan memiliki arti sebagai penunjuk kala yang akan datang.

Contoh : nanti malam kita mopigi panana perumah

'nanti malam saya akan pergi kerumahmu'

/mo/ + /pigi/menjadi /mopigi/ 'akan pergi'

Prefiks (tar-) berarti mengalami atau dikenai apa yang disebut pada kata dasar dan membentuk kata kerja pasif.

Contoh : tarpaksa kita musti pigi no

'saya harus pergi secara terpaksa'

/tar/ + /paksa/ menjadi /tarpaksa/ 'terpaksa'

13. Akhiran (-akan) yang didahului baik oleh kata kerja, kata benda dan kata sifat akan menjadi kata meminta tolong atau membentuk kata kerja kausatif.
Contoh :
/foto/ + /akay menjad
/foto akay/ 'tolong difoto'
/pange/ + /akay/menjadi
/panyeakay/ 'tolong dipanggilkan'
/pend $\varepsilon /+/$ akay/menjadi
/pendeakay/ 'tolong dipendekkan'

14. Akhiran (-an) apabila dipasangkan dengan kata kerja, kata sifat, kata bilangan dan kata keterangan akan menjadi kata benda.

$\begin{array}{llll}\text { Contoh : } & \text { /buykus/ + /an/menjadi } & \text { /bujkusan/ } & \text { 'bunngkusan' } \\ & \text { /manis/ + /an/ menjadi } & \text { /manisan/ } & \text { 'manisan' } \\ & \text { /puluh/ + /an/ menjadi } & \text { /puluhan/ } & \text { 'puluhan' } \\ & / \text { sampin/ } / \text { /an/menjadi } & \text { /sampingan/ } & \text { 'sampingan' }\end{array}$

15. Prefiks (ka-) akan merubah kata bilangan menjadi ordinal.
Contoh
$/ \mathrm{ka} /+/ \mathrm{satu} /$ menjadi
/kasatu/
'kesatu' 
16. Prefiks (ka-) akan membentuk kata keterangan tempat menjadi keterangan arah.
Contoh
$/ \mathrm{ka} /+$ /atas/ menjadi
/kaatas
'keatas'

17. Konfiks (ka-an) akan membentuk kata benda dari kata sifat.
Contoh :
/ka-an/ + /susah/ menjadi
/kasusahan
'kesusahan'

18. Konfiks (ka-an) akan membentuk kata sifat dari kata keterangan.

Contoh : /ka-an/ + /abis/menjadi /kaabisan/ 'kehabisan'

19. Konfiks (paN-an) akan membentuk kata benda dari kata kerja.

Contoh : /paN-an/ + / cari/menjadi /pancarian/ 'pencarian'

$/ \mathrm{paN}-\mathrm{an} /+/ \mathrm{aku} /$ menjadi /panakuan/ 'pengakuan'

/paN-an/ + /bage/menjadi /pambagean/ 'pembagian'

\section{Reduplikasi}

Bahasa Melayu Manado memili dua bentuk reduplikasi berupa:

1. Reduplikasi utuh

perulangan seluruh elemen bentuk dasar tanpa variasi vokal atau konsonan. Terdiri dari :

a. Reduplikasi utuh bentuk dasar tunggal. Terdiri atas :

1. perulangan menyatakan jamak apabila akar katanya adalah kata benda.

Contoh : /tanta/ 'tante' menjadi /tanta tanta/

2. perulangan meyatakan berbagai jenis.

Contoh : /sayor/ 'sayur' menjadi /sayor sayor/

3. perulangan menyatakan repetisi.

Contoh : /sayor sayor jo hari hari/ 'setiap hari hanya sayur saja'

4. perulangan menyatakan untuk bersenang-senang.

Contoh : /dudu/ 'duduk' menjadi /dudu dudu/

5. perulangan menyatakan perbuatan yang dilakukan berulang kali.

Contoh : /gigi/ 'gigit' menjadi /gigi gigi/

6. kata dasar yang trisuku tetapi hanya suku pertama yang diulang.

Contoh : /momasa/ 'memasak' menjadi /momomasa/

7. perulangan bentuk dasar kata sifat

Contoh : /basar/ 'besar' /tu lemon di pasar basar basar/ 'jeruk yang di pasar itu besar besar bentuknya/

1. bila bentuk dasar kata kerja, perulangan menyatakan perbuatan yang dilakukan berulang kali sehingga menjadi kebiasaan.

Contoh : /makay/ 'makan' menjadi /makan makay/

2. bila bentuk dasar kata ganti orang atau kata penunjuk ini dan itu maka perulangan menyatakan orang / benda yang sama secara teru menerus.

Contoh : /kita/ 'saya' menjadi /kita kita/ /kita kita jo/ 'hanya saya saja terua menerus'

b. Reduplikasi utuh bentuk kompleks.

Perulangan seluruh kata dasar yang berbentuk kompleks. Terdiri atas :

1. perulangan menyatakan perbuatan / keadaan / proses yang terjadi terus menerus.

Contoh : /baputar/ 'berputar' menjadi /baputar baputar/

2. perulangan menyatakan jamak.

Contoh : /panako/ 'penakut' menjadi /panako panako/ 
2. Reduplikasi partial.

Ini terjadi pada bentuk-bentuk yang berimbuhan. Proses perulangan terjadi pada imbuhan, akar kata maupun pada gabungan keduanya. Terdiri atas :

a. bentu-bentuk dasar berawalan /ba-//bar-//bor-//ka-/ yang direduplikasikan.

Contoh : /barumpu/ 'mengotori' menjadi /babarumpu/

b. Perulangan yang menyatakan suatu aktivitas yang sedang dilakukan.

Contoh : /batobo/ 'berenang' menjadi /babatobo/

c. Bentuk-bentuk dasar berawalan /ta-/ menyatakan suatu keadaan / peristiwa yang terjadi berulang kali.

Contoh : /tatidor/ 'tertidur' menjadi /tatatidor/

d. Bentuk-bentk dasar berawalan /ba-/ atau /ta-/meyatakan berulang kali.

Contoh : /bagoyay/ 'bergoyang' menjadi /babagoyay/

3. Reduplikasi bentuk/baku/

Contoh : /baku goso/ 'gosok menggosok' menjadi /baku baku gosok/

4. Reduplikasi bentuk akhiran /-akay/

Contoh : /taña akan/ menjadi /taña taña akay/

\section{Kesimpulan}

Bahasa Melayu Manado memiliki proses morfologis yang dapat diterapkan pada bentukbentuk kata yang merupakan bagian dalam bahasa. Proses afiksasi yang terjadi dapat juga duterpakan dalam bentuk penambahan prefiks, sufiks dan konfis. Bahasa Melayu Manado juga memiliki dua jenis proses reduplikasi yang dapat menunjukkan keunikan tersendiri dalam penjabarannya.

\section{Daftar Pustaka}

Acmad, HP dan Alek Abdullah. 2012. Linguistik Umum. Jakarta: Erlangga.

Alwi, Hasan dan Darmowidjojo,Soejono dan M Moeliono,Anton. 2003. Tata Bahasa baku Indonesia. Jakarta: Pusat Bahasa dan Balai Pusataka.

Arifin, zaenal dan Tasai,amran. 2010. cermat berbahasa indonesia. Jakarta: akademika presindo. Budiharjo, E. (2012). Dari Globalisasi ke Glo-kalisasi. pada www.kompas.co.id yang diakses pada 26 Desember 2012.

Chaer, Abdul dan Leoni Agustin.2004. Sosiolinguistik: Perkenalan Awal. Jakarta:

Chaer, Abdul. 2009. Psikolinguistik Kajian Teoretik. Jakarta:PT. Rineka Cipta.

Chang, J. S. 2004. Refashioning Womanhood in 1990s Taiwan: An Analysis of Taiwanesse 'Cosmopolitan' Magazine. Modern China volume 30 (3).

Djajasudarma, Fatimah.1993. Semantik I (Pengantar Ke Arah Ilmu Makna).

Imbang, Djeinnie, 2008. Bentuk Makna dan Fungsi Kata Tugas dalam Bahasa Melayu Manado; Fakultas Ilmu Budaya Unsrat: Manado

Kasali, Rhenald. 2007. Manajemen Periklanan. Jakarta: Pustaka Utama Grafiti.

Moleong, Lexy. J. 2006. Metodologi Penelitian Kualitatif. Bandung: Rosda Karya

Nurdin, Anas, 2015. Fungsi Adverbial Bahasa Melayu Manado. Pascasarjana Unsrat: Manado

Ritzer, G. 2003. Rethinking Globalization: Glocalization/Grobalization and Something/Nothing. Sociological Theory volume 21 (3).

Suyanto, Edi. 2016. Cara Mudah Belajar Bahasa Indonesia Secara Benar. Utama, Jakarta.

Sugono, Dendy. 2009. Mahir Berbahasa Indonesia. Jakarta: gramedia. 
Whorf, B.L, 1956. Language, Thought and Reality. New York: MIT Pr Widyatama, Rendra. 2011. Teknik Menulis Naskah Iklan. Jakarta: Cakrawala.

Widjono. 2012. Bahasa Indonesia. Jakarta: Grasindo.

Winanti, P. S. (2003).Developmental State dan Tantangan Globalisasi: Pengalaman Korea Selatan. Jurnal Ilmu Sosial dan Ilmu Politik Universitas Gadjah Mada Yogyakarta, Vol. 7, No. 2, No-vember 2003, hal. 180. 